Социально-исторический подход в психологии обучения / [под ред. М. Коула]. - М. : Педагогика, 1989. 2. Полат Е. С. Дистанционное обучение: Каким ему быть? / Е. С. Полат, А. Е. Петров // Педагогика. - 1999. - № 7. 3. Педагогико-эргономические условия безопасного и эффективного использования средств вычислительной техники, информатизации и коммуникации в сфере общего среднего образования // Информатика и образование. - 2002. - №1. 4. Касаткин Д. Ю. Условия реализации компьютерно-ориентированных учебных сред / Д. Ю. Касаткин // Развитие образования в России // Материалы международной научно-практической конференции. - Новосибирск, 2011. - С. 65-77.

УДК 371.4:37

\author{
Н. Т. Тверезовська, \\ доктор пед. наук, професор, \\ T. В. Тарнавська, \\ дочент, \\ природокористування Украӥни
} Національний університет біоресурсів $i$

\title{
ОСМИСЛЕННЯ ПОНЯТТЯ «СИСТЕМА» В РІЗНИХ ГАЛУЗЯХ НАУКОВИХ ЗНАНЬ
}

У статті розглянуто тлумачення терміна «система» в різних галузях наукових знань. Простежено історію становлення та розвитку принцииу иілісності в наукових дослідженнях. Розглянуто визначення понять, які характеризують будову та функиіонування систем: елемент, підсистема, компонент, зв'язок, мета, структура, стан системи, рівновага, стійкість, розвиток, адаптація.

Ключові слова: система, системні уявлення, ијілісність, властивості систем.

В статье рассмотрено толкование термина «система» в различных областях научных знаний. Прослежена история становления и развития приниипа иелостности в научных исследованиях. Рассмотрены определения понятий, характеризующих строение и функиионирование систем: элемент, подсистема, компонент, связь, цель, структура, состояние системь, равновесие, устойчивость, развитие, адаптация.

Ключевые слова: система, системные представления, целостность, свойства систем.

In the article rassmotreno tolkovanye termyna «system» of various regions in nauchny'h knowledge. Proslezhena story stanovlenyya and Development integrity principle in nauchny'h study. Address the definition of concepts, harakteryzuyuschyh stroenie and functioning systems: element, podsystema, components, communications, goal, structure, the state system, equilibrium, Stability, development, adaptation.

Key words: system, integrity, properties of systems. 
В умовах постійного зростання обсягу інформації перед системою професійної підготовки фахівців постала проблема інтенсифікації освітнього процесу шляхом інформатизації освіти, що грунтується на впровадженні інформаційних технологій у навчальний процес. Головною концептуальною засадою їх застосування є системний підхід, тому дослідження цієї проблеми передбачає розгляд тлумачень поняття «система» в різних галузях наукових знань.

Важливий внесок у розвиток системного підходу зроблено А. Богдановим (поняття системності, комплексії, кон'югації, інгресії, дезінгресії; ідея про структурну стійкість системи; формуючі та регулюючі закономірності системи), Л. Берталанфі (загальна теорія систем), В. Садовським, Є. Юдіним, I. Блаубергом (переклад перших закордонних наукових праць з системного підходу, філософія і методологія системних досліджень), Н. Волковою, А. Денісовим (теорія систем), Ф. Перегудовим, Ф. Тарасенко (методи прикладного системного аналізу), Г. Саймоном (теорія прийняття рішень, у якій визначено ділову фірму як адаптивну систему, що включає матеріальні, людські і соціальні компоненти, пов'язані між собою комунікаційною мережею і загальним прагненням іiі членів співпрацювати для досягнення спільної мети). У соціології системно-органістичні уявлення про суспільство розвивали О. Конт і Г. Спенсер, Т. Парсонс; психології - Дж. О’Коннор та І. Макдермотт, фізіології - П. Анохін та ін. Проте єдиного розуміння поняття «система» й досі не існує, що зумовлює актуальність досліджень у цій галузі наукового знання.

Mema cmammi - розглянути тлумачення терміна «система» в різних галузях наукових знань; розглянути історію становлення та розвитку принципу цілісності в наукових дослідженнях.

Активна розробка проблеми системності знань 3 осмисленням поняття «система», на думку Е. Агошкової, Б. Ахлибининського розпочалася у XVIII ст., коли у двох протилежних напрямах в теорії пізнання - емпіричному і раціоналістичному - загострилося протистояння щодо системності науки, тривало до кінця XIX ст., коли багато теоретиків (Е. Max, Р. Дінглер) повністю відмовилися від онтологічних підстав пізнання, а система розглядалася як результат діяльності суб'єкта пізнання. На думку науковців, цей напрям не 
сформував поняття система, оскільки «знання загалом, як $\mathrm{i}$ світ загалом - об’єкт нескінченний, і тому принципово не співвідноситься $з$ поняттям «система». Із сучасних позицій зрозуміло, що це поняття є способом кінцевого подання нескінченно складного об'єкта, і в цьому полягає його гносеологічна сутність.

Наприкінці XIX - на початку XX ст. принцип цілісності набув популярності в наукових дослідженнях. Цей період позначився відмовою від таких світоглядних позицій, як елементаризм, який стверджував, що складні явища можна зрозуміти тільки через їх елементарні складники та механіцизм, що зводив складні закономірності розвитку до найпростіших законів механіки.

Цілісність, за визначенням С. Щерби, О. Заглади, «є узагальненою характеристикою об'єктів, єдністю частин у різноманітних їх зв’язках. Орієнтація на принцип цілісності дозволяє перебороти обмежені способи дослідження: елементаризм (розчленування цілого на частини), механіцизм (розуміння цілого як суми частин) та редукціонізм (зведення складного до простого). Дослідження цих категорій сприяло розвитку системного підходу до пізнання різних об'єктів, відкрило шлях до формування категорій «елемент», «структура», «система». Поняття зв'язку сприяло становленню та розвитку уявлень про способи впорядкованості різних об'єктів» [1].

У соціології, як зазначає Н. Черниш, в основу однієї з перших цілісних концепцій соціальної системи (В. Парето) покладено механістичне розуміння суспільства, яке складається iз сукупності соціальних атомів-людей, подібно до природної системи, яка збудована 3 атомів і молекул. За визначенням В. Парето, суспільство - це система, яка перебуває у стані рівноваги, але рівноваги відносної, яка постійно порушується і відновлюється. Всі частини соціальної системи тісно взаємопов'язані й механічно впливають одна на одну.

На зміну елементаризму та механіцизму прийшов органіцизм - методологічний принцип, відповідно до якого соціальні явища розглядалися за аналогією з природними. В соціології системно-органістичні уявлення про суспільство розвивали О. Конт і Г. Спенсер, визначивши соціальну систему як складне ціле, що формується за законами доцільності. Це динамічне утворення, яке перебуває в постійному розвитку, як будь-який живий організм. На відміну від механістичних уявлень про суспільство, органіцизм звертає увагу передов- 
сім на динамічні процеси всередині соціальних систем. Однак механічне перенесення біологічних закономірностей на суспільство виявилося неспроможним забезпечити наукове розуміння його законів. Водночас І. Блауберг і Е. Юдін уважають, що елементаристський підхід і досі має велике методологічне значення в наукових дослідженнях i, як приклад, наводять кібернетику, яка до таких «атомів», як речовина та енергія, додає інформацію.

Досліджуючи генезу поняття «система», А. Бабайцев зазначає, що для іiі розуміння важливим є момент включення міфологічних уявлень про Космос, Світовий порядок, Сдине в контекст власне філософсько-методологічних міркувань, коли система поступово стає предметом пізнання. У процесі еволюції поняття «система» змінювало своє значення від епістемолого-методологічного в античності до чисто епістемологічного тлумачення (Евклід, Кант) і 3 початку XIX ст. онтологічного та натуралістичного тлумачення: головним завданням стає не стільки формування системи знань, скільки відтворення у знанні об'єкта як системи. Із розвитком інженерного підходу і технологій у ХX ст. А. Бабайцев пов'язує штучно-технічний період пізнання системи, коли іiі не тільки досліджують, а й проектують і конструюють. Початком швидкого розповсюдження поняття «система» (середина ХХ ст.) у різних галузях конкретно-наукового знання, характерною особливістю системного руху стають міжпрофесійні і міжсистемні дослідження.

Важливою подією в розвитку системних уявлень уважається публікація у 1948 році книги Н. Вінера «Кібернетика». На думку Дж. Гіга, саме 3 моменту появи кібернетики системні дослідження почали свій справжній розвиток завдяки У. Ешбі, О. Ланге та багатьом іншим ученим, які забезпечили для цього наукову і технічну базу та досвід проектування автоматизованих систем. О. Горбань, В. Бахрушин уважають, що 3 кібернетикою пов'язані такі досягнення, як «типологізація моделей систем, виявлення особливої ролі зворотних зв'язків у системах, формулювання й застосування принципу оптимальності в управлінні ними та їх синтезі, усвідомлення інформації як загальної властивості систем і розробка методів ії кількісного опису, розвиток методології математичного моделювання й математичного експерименту за допомогою EOM» [2, с. 9]. На відміну від позиції Л. Берталанфі, який особливу увагу приділяв вивченню обміну системи із зовні- 
шнім середовищем речовиною, енергією та інформацією, вінеровський підхід передбачає вивчення зворотних зв'язків усередині системи, а функціонування системи розглядається як реакція на зовнішній вплив.

Суперечливість визначень поняття «система» у різних авторів Е. Агошкова, Б. Ахлибининський пояснюється тим, що дослідники розробляли його в різному сенсі: онтологічному, гносеологічному або методологічному. Онтологічний сенс визначення терміна «система» у Древній Греції пояснюється ототожненням онтологічного аспекту самої реальності і гносеологічного аспекту знання про неї. В онтологічному підході до визначення терміна «система» автори виокремлюють дві гілки: 1) усвідомлення систем як цілісних і водночас розчленованих фрагментів реального світу і 2) використання терміна «система» не для розчленованого цілого, а, навпаки, для «цілісності, яка визначається певною спільністю, яка організує таке ціле». Тобто система як сукупність об'єктів і система як сукупність властивостей. Важливим $\epsilon$ те, що формування поняття «система» 3 терміна «система» здійснюється через усвідомлення цілісності і розчленованості як природних, так і штучних об'єктів. Це відображено у тлумаченнях системи як «цілого, складеного 3 частин» (Г. Галілей, I. Ньютон, У. Гамільтон, П. Лаплас, П. Гольбах, Р. Декарт, Б. Спіноза, Л. Берталанфі).

Нині термін «система» є ключовим в усіх галузях наукових досліджень. У психології організм людини розглядається як ціле, яке $\epsilon$ складником більш складного цілого, із якого воно походить. Л. Столяренко підкреслює зв'язок організму 3 природою i використання ним фізичних закономірностей природи: «організм існує тільки в природному середовищі, у процесі систематичного обміну продуктами з природним середовищем і полягає глибинний, фундаментальний зв'язок нашого органічного існування з природою» [3]. Поняття «система» у психології пов'язано з біологічною проблемою цілісної особистості. «У дев'ятнадцятому столітті біологічна наука особливу увагу приділяла клітині як основному матеріалу, із якого будується живий організм, що як цілісність залишався осторонь. Нині ситуація змінилася, і проблема цілісного організму стала предметом плідних досліджень. У сучасній науці ця проблема розробляється в кількох напрямках: в аспекті вивчення конституції тіла, внутрішньої секреції і нервової системи» [3]. 
Із позицій біхевіоризму людина як особистість розглядається як організована і відносно стійка система навичок. Складні структурні утворення психічних властивостей людини теж розглядаються, як системи: життєва позиція особистості - це система потреб, інтересів, переконань та ідеалів, яка визначає рівень активності людини; темперамент - це система природних властивостей особистості - рухливість, урівноваженість поводження і тонус активності; здібності це система інтелектуально-вольових і емоційних властивостей, яка визначає творчі можливості особистості; характер це система відносин і способів поведінки [3].

Починаючи 3 20-х років термін «система», на думку А. Асмолова, міцно закріпився в психології особистості. Нині практично всі дослідники особистості одностайні в твердженні, що достатньо глибоке розуміння особистості можливе тільки за умови вивчення людини як цілісної системи. Тенденція до системного відношення до людини в психології почала швидко розвиватися після появи загальної теорії систем Л. Берталанфі. Г. Оллпорт (1960 р.) розглядає особистість як відкриту систему, що взаємодіє з дійсністю. Спільною рисою цих концепцій є прагнення представити особистість як цілісний об'єкт, дослідження особистості як системи.

Фундаментальна категорія соціології - соціальна система - визначається як цілісна структура, основним елементом якої є люди, їх взаємодії, відносини і зв'язки. Соціальні системи складаються на основі свідомої поведінки людини, спрямованої на іншого. Німецький соціолог Н. Луман уточнює поняття соціальних систем як систем комунікації, заснованих на узгодженні взаємних очікувань учасників цього процесу. Комунікація $\epsilon$ найменшою з можливих одиниць соціальної системи і розглядається як триєдність інформації, повідомлення і розуміння.

Психологи Дж. О’Коннор і I. Макдермотт визначають систему як «сутність, яка в результаті взаємодії іiі частин може підтримувати своє існування і функціонувати як єдине ціле» $[4$, с. 26]. Розуміючи, що метод вивчення подій шляхом логічного поділу на складники, а потім возз'єднання в ціле, не завжди зумовлює успіх, автори дійшли висновку, що системне мислення - це шлях до творчого розв'язання проблем. На їхню думку, люди і події не підкоряються законам логіки, їх важче передбачити і ними важче керувати, ніж математичними рівняннями. Для них непридатні швидкі, методичні, 
логічні рішення. Звичне причинне мислення не спрацьовує, коли вам доводиться мати справу з системами, тому що воно скрізь убачає дію простих, локалізованих в просторі і в часі причинно-наслідкових зв'язків, а не комбінацію чинників, які обопільно впливають один на одного» [4, с. 23].

Соціологія розглядається суспільством як особливий тип макросистеми, підсистемами якої є індивіди, соціальні дії, відносини та взаємодії, що є стійкими і відтворюються в історичному процесі, переходячи 3 покоління в покоління. Із позиції прихильників системного підходу, суспільство $\epsilon$ цілісною, а не сумарною, системою, і на рівні суспільства індивідуальні дії, зв'язки і відносини створюють нову, системну якість. Системна якість, за визначенням А. Брегеди, - це особливий якісний стан, який не можна розглядати як звичайну суму елементів. Соціальна дія, один із найпростіших елементів соціальної системи, - це людська поведінка, якій суб'єкт надає певного сенсу (мотивації). Мотивом соціальної дії $\epsilon$ формування особистої мети, яка спрямована на задоволення власної потреби з урахуванням можливої реакції оточення. Дію, яка спрямована на іншу людину (а не на фізичний об'єкт) і породжує зворотну реакцію, кваліфікують як соціальну взаємодію.

Із позицій системної побудови суспільства, Т. Парсонс визначив чотири основні функції, характерні для всіх соціальних систем: 1) адаптація: будь-яка соціальна система пристосовується як до внутрішньої ситуації, так і до змін зовнішнього середовища; 2) ціледосягнення: система визначає й досягає поставлених цілей; 3) інтеграція: система пов'язує й зумовлює всі свої компоненти та функції; 4) збереження зразка: будь-яка соціальна система створює, вдосконалює, зберігає, оновлює мотивацію індивідів, зразки їхньої поведінки, культурні принципи.

Однак П. Анохін вважає неспроможними формулювання поняття системи, які грунтуються тільки на «взаємодії» та «впорядкуванні» компонентів. «Взаємодія сама по собі не може сформувати систему, оскільки аналіз дійсних закономірностей функціонування 3 позиції функціональної системи розкриває скоріше механізм «сприяння» компонентів, ніж їх «взаємодії». Системою П. Анохін називає «тільки такий комплекс вибірково залучених компонентів, у яких взаємодія та взаємовідносини набувають характеру взаємосприяння ком- 
понентів на отримання фокусованого корисного результату» [5].

На думку Р. Макарова, визначення поняття системи Д. Анохіна можна вважати найбільш конструктивним у методологічному аспекті для досліджень, у яких об'єктом впливу $є$ людина. Автор пропонує таке формулювання поняття педагогічної системи професійної підготовки: «комплекс ефективних засобів, специфічних процесуальних принципів, змісту, методів і прийомів формування професійно значущих якостей, методів і критеріїв оцінки професійної готовності, функціонування яких детерміновано метою професійної підготовки та принципами конструювання моделей професійної підготовки, що фокусують міжпредметні зв'язки і відносини у розв'язанні педагогічних завдань такої підготовки» [6, c. 135].

Головною проблемою, яка визначає поняття системи i стратегію його застосування в наукових дослідженнях, на думку П. Анохіна, $є$ пошук і формулювання системоутворюючого фактора. Чи принесе користь конкретним наукам системний підхід, залежить від того, наскільки успішно виділено системоутворюючий фактор і наскільки повно описано операціональне значення для формування системи. Тільки за цієї умови можна застосувати принципи системоутворення для всіх тих класів явищ, у яких відбувається упорядкування.

На підставі аналізу багатьох визначень системи В. Садовський, Є. Юдін подають такий інваріант значення цього терміна: 1) система - це цілісний комплекс взаємопов'язаних елементів; 2) утворює особливу єдність із середовищем; 3) як правило, є елементом системи більш високого рівня; 4) елементи будь-якої досліджуваної системи, у свою чергу, зазвичай виступають як системи більш низького рівня.

Д. Узнадзе визначає такі ознаки, властиві будь-якій системі: 1) щось цілісне, відмінне від навколишнього середовища; 2) цілісність носить функціональний характер; 3) систему можна диференціювати на кінцеву безліч взаємопов'язаних елементів, які мають цілком визначені властивості; 4) окремі елементи взаємодіють задля загального призначення системи; 5) властивості системи не зводяться до властивостей компонентів, що іiі утворюють; 6) система знаходиться в інформаційній та енергетичній взаємодії з навколишнім середовищем; 7) система змінює характер функціонування зале- 
жно від інформації про отримані результати; 8) системи можуть мати властивості адаптивності.

Проте єдиного розуміння системи й досі не існує. 3'ясовуючи причини такої ситуації, Е. Агошкова, Б. Ахлибининський дійшли висновку, що найбільш характерні відмінності у визначеннях системи пов'язані, по-перше, 3 тим, до чого відноситься поняття «система». Це може бути: об'єкт (річ) в цілому (будь-якому або специфічному); сукуnність об'єктів (розчленована природно або штучно); не об'єкт (річ), а подання об'єкта через сукупність елементів, що перебувають у взаємозв'язках; сукупність елементів, що перебувають у взаємозв'язках.

Інші відмінності полягають у тому, що для сукупності елементів не завжди висувається вимога утворювати цілісність, єдність (конкретизовану або не конкретизовану); «ціле» може бути первинним щодо сукупності елементів або похідним від сукупності елементів; поняття «система» може стосуватися всього, що дослідник вважає системою, або тільки такої сукупності, яка включає специфічну «системну» ознаку. Різним є і ставлення дослідників до існування «несистем». На підставі такого аналізу автори роблять висновок про те, що системою $є$ форма подання предмета наукового пізнання. I в цьому сенсі вона $є$ фундаментальною й універсальною категорією. Наявність великої кількості тлумачень підтверджує справедливість висловлювання В. Садовського про те, що поняття «загальна теорія систем», не має чітко визначеного розуміння, і йдеться не про єдину концепцію, а про «новий напрямок дослідницької діяльності, про вироблення нової системи принципів наукового мислення, про формування нового підходу до об'єктів дослідження».

Зазнавши тривалої історичної еволюції, поняття «система» 3 середини ХX ст. стає одним 3 ключових філософськометодологічних і спеціально-наукових понять. Будову та функціонування систем характеризують такі поняття, як елемент, підсистема, компонент, зв'язок, мета, структура, стан системи, рівновага, стійкість, розвиток, адаптація. Розглянемо визначення цих понять у дослідженнях В. Бахрушина, В. Волкової, Дж. Гіга, О. Горбаня, Ф. Перегудова, I. Блауберга, В. Ягупова, Ю. Жука та інших.

Елементом системи називають найпростішу складову частину системи, яка залежно від конкретних завдань і мети дослідження умовно розглядається як неподільна. У системі, 
яка $є$ органічним цілим, елемент визначається як мінімальна одиниця, здатна відносно самостійно виконувати певні функції. Наприклад, взаємопов'язаними елементами системи навчального процесу є мета, навчальна інформація, засоби педагогічної взаємодії суб'єктів викладання й учіння, форми їх взаємодії тощо. Елементи, які надходять до системи, називають вхідними, а ті, що з неї виходять, - вихідними. Окрім вхідних елементів, виокремлюють поняття «ресурси». Дж. Гіг зазначає, що різниця між ними залежить від точки зору та умов. Наприклад, студенти, які входять на рівні суб' єктів до системи освіти, є вхідними елементами, а викладачі - один із ресурсів; а в межах складної, багаторівневої системи, коли студенти стають активними елементами суспільства, вони перетворюються на ресурси. Вихідні елементи це результат процесу перетворення в системі.

Підсистемою називають відносно незалежну складову частину системи, яка має властивості системи й у якій можна виокремити інші частини. Складники, які не мають властивостей системи, а $є$ просто сукупністю однорідних елементів, називають компонентами системи. Наприклад, основними компонентами моделі навчального процесу, на думку В. Ягупова, мають бути цільовий, стимулювальномотиваційний, змістовий, процесуальний, контрольнорегулювальний, оцінково-результативний та суб'єктсуб'єктний. Співвідношення між компонентами системи, що грунтуються на взаємозалежності і взаємозумовленості, визначають як зв'язок. Зв'язок характеризує чинники виникнення й збереження цілісності системи та іiі властивостей. Його можна охарактеризувати за напрямом (спрямовані й не спрямовані), силою (сильні та слабкі) та характером або видом (управління, підпорядкування, породження, або генетичні, рівноправні, або байдужі) та за місцем розташування (внутрішні й зовнішні), спрямованістю процесів у системі загалом або в окремих їі підсистемах (прямі і зворотні) та за іншими більш конкретними ознаками.

Метою системи називають іï бажаний майбутній стан. Мету навчального процесу як системи слід визначати з урахуванням такої моделі людини, яка, буде мати змогу стати активним учасником подій, що відбуватимуться в майбутньому суспільстві, характерною ознакою якого буде повсюдне використання інформаційних і комунікаційних технологій. Мета, яку ставить перед собою людина, рідко досяжна тільки 
за рахунок iї власних можливостей або зовнішніх засобів, наявних у неї в певний момент. Такий збіг обставин Ф. Перегудов називає проблемною ситуацією. Проблемність ситуації усвідомлюється в кілька «етапів»: відчуття, що «щось не так»; усвідомлення потреби; виявлення проблеми; формулювання мети. За визначенням Ф. Перегудова, мета це суб' єктивний образ (абстрактна модель) неіснуючого, але бажаного стану середовища.

Під структурою системи розуміють сукупність необхідних і достатніх відношень між ії компонентами для досягнення мети. Структура характеризує організованість системи, стійку упорядкованість іiі елементів і зв'язків. Як зазначає Ю. Жук, «розглядаючи навчальний процес як структуру, ми вивчаємо ті взаємозв'язки та відношення, які змінюються повільно, визначаючи якісну своєрідність учіння: його інформаційний і діяльнісний складники, прямий та обернений зв'язки, місце та роль кожного з учасників навчального процесу, структуру навчального середовища (його змістовне i матеріальне наповнення)» [7]. Структура може бути простою чи складною залежно від кількості і типу взаємозв'язків між елементами системи. Для складних систем велике значення має ієрархія.

За К. Сорокою, стан системи - це сукупність значень іï параметрів (або властивостей) у певний момент часу, а ії рівновага - це здатність системи за відсутності зовнішніх впливів зберігати свою поведінку як завгодно довго. Стан системи характеризується показниками іï ознак у певний момент. Під стійкістю стану системи розуміють ситуацію, коли малим змінам зовнішніх впливів відповідають малі зміни вихідних параметрів системи або ії властивостей. Поведінка системи це іï здатність переходити з одного стану в інший. Зокрема, поведінка навчальної системи характеризується циклічністю, динамічністю, розвитком. Зміни стану системи з часом характеризує розвиток, допомагаючи пояснити складні інформаційні процеси у природі та суспільстві. Виокремлюють еволюційний та стрибкоподібний (революційний) розвиток. У першому випадку характеристики з часом змінюються повільно, структура системи залишається незмінною. У другому - спостерігаються різкі стрибкоподібні зміни окремих параметрів системи, можуть змінюватися іiі будова й характер зв'язків між компонентами. Процеси пристосування системи до зовнішнього середовища, унаслідок яких підвищується 
ефективність іiї функціонування, називають адаптацією системи.

Зазнавши тривалої історичної еволюції, поняття «система» стало одним 3 ключових філософсько-методологічних $\mathrm{i}$ спеціально-наукових понять. Будучи предметом наукового пізнання, система $\epsilon$ фундаментальною й універсальною категорією.

Актуальними напрямками подальшого розроблення окресленої проблеми є дослідження діяльнісного й аксіологічного підходів до застосування інформаційних технологій у навчальному процесі ВНЗ.

\section{Література}

1. Щерба С. П. Філософія: [підручник] / С. П. Щерба, О. А. Заглада. - [3-є вид.]. - Житомир : Полісся, 2009. - 548 с. 2. Фіцула М. М Основи теорії систем та системного аналізу / М. М. Фіцула. - Запоріжжя : ГУ ЗІДМУ, 2004. - 204 с. 3. Столяренко Л. Д. Основы психологии / Л. Д. Столяренко. - [3-е изд., пер. и доп.]. - Ростов-на-Дону : Феникс, 2000. - 672 с. - (Cерия: Учебники, учебные пособия). 4. О'Коннор Дж. Искусство системного мышлении: необходимые знания о системах и творческом подходе к решению проблем / Джозеф О'Коннор, Иан Макдермотт; [пер. с англ. Б. Пинскера]. - М. : ЦНТУ, 2006. - 222 с. 5. Анохин П. К. Основные положения теории функциональных систем [Електронний ресурс] / П. К. Анохин. - Ч. 5: Понятие системы. - Режим доступа : http://dargo.ru/publ/39-1-0-272. - Заголовок с экрана. 6. Макаров Р. Н. Основы формирования профессиональной надежности летного состава гражданской авиации: [учеб. пособ.] / Р. Н. Макаров. - М. : Воздушный транспорт, 1990. - 384 с. 7. Жук Ю. О. Системні особливості освітнього середовища як об’єкта інформатизації / Ю. О. Жук // Післядипломна освіта в Україні. -2002 . - № 2. - C. 35-37. 